\title{
ASSOCIATION OF THE MTHFR 677C>T POLYMORPHISM WITH OBESITY AND BIOCHEMICAL VARIABLES IN A YOUNG POPULATION OF MEXICO
}

\author{
POVEZANOST MTHFR 677C>T POLIMORFIZMA SA GOJAZNOŠĆU I BIOHEMIJSKIM \\ PROMENLIVIMA U MLADOJ POPULACIJI MEKSIKA
}

\author{
Evelia Leal-Ugarte1, Valeria Peralta-Leal ${ }^{1}$, Juan Pablo Meza-Espinoza1 , Jorge Durán-González ${ }^{1}$, \\ Nelly Macías-Gómez ${ }^{2}$, Anabel Bocanegra-Alonso ${ }^{3}$, José Ramón Lara-Ramos ${ }^{3}$ \\ ${ }^{1}$ Facultad de Medicina e Ingeniería en Sistemas Computacionales de Matamoros, Universidad Autónoma de \\ Tamaulipas, Sendero Nacional km 3, Col San José, Matamoros, Tamps., México \\ ${ }^{2}$ Centro Universitario del Sur, Universidad de Guadalajara, Av. Enrique Arreola Silva \# 883, \\ Col Centro, Ciudad Guzmán, Jal., México \\ 3 Unidad Académica Multidisciplinaria Reynosa-Aztlán, Universidad Autónoma de Tamaulipas, \\ Calle 16 y Lago de Chapala, Col Aztlán, Reynosa, Tamps., México
}

\begin{abstract}
Summary
Background: Methylenetetrahydrofolate reductase (MTHFR) gene polymorphisms have been associated with overweight people and obesity. The goal of this study was to investigate the relationship of the MTHFR $677 \mathrm{C}>\mathrm{T}$ polymorphism with obesity and biochemical variables in young individuals of Mexico.

Methods: A total of 316 young individuals were included in the study, 172 with normal weight (NW) and 144 with overweight/obesity. Body mass index (BMI) was classified as NW, overweight, and obesity. Also, waist circumference was measured. Moreover, glucose, total cholesterol, and triglycerides were determined. Genotyping for MTHFR $677 C>$ T polymorphism was performed by the PCR-RFLP method.

Results: There was no difference in the distribution of the MTHFR 677 C $>$ T polymorphism between individuals with NW and overweight/obesity; neither when they were divided by overweight vs NW, nor when we contrasted obese vs NW. However, an analysis stratified by gender showed a significant protector effect of the TT genotype against obesity in males and elevated waist circumference
\end{abstract}

Address for correspondence:

Evelia Leal-Ugarte

Facultad de Medicina e Ingeniería en Sistemas

Computacionales de Matamoros, Universidad Autónoma

de Tamaulipas, Sendero Nacional km 3, Col San José,

Matamoros, Tamps., México

Phone: +52 8682044000

Fax: +52868204 4001

e-mail: elugarte@docentes.uat.edu.mx

\section{Kratak sadržaj}

Uvod: Polimorfizam genetske metilenetetrahidrofolat reduktaze (MTHFR) je povezan sa prekomernom težinom $\mathrm{i}$ gojaznošću. Cilj ove studije bio je da se istraži odnos MHTFR $677 \mathrm{C}>\mathrm{T}$ polimorfizma sa gojaznošću i biohemijskim promenjivim kod mladih u Meksiku.

Metode: U studiju je uključeno ukupno 316 mladih osoba, 172 sa normalnom težinom (NV) i 144 sa prekomernom težinom/gojaznih. Indeks telesne mase (BMI) je klasifikovan kao NT (normalna težina), prekomerna težina i gojaznost. Takođe, izmeren je obim struka. Štaviše, određena je i glukoza, ukupni holesterol i trigliceridi. Genotipizacija za MTHFR 677C > T polimorfizam je izvedena metodom PCRRFLP.

Rezultati: Nije postojala razlika u distribuciji MHTFR $677 \mathrm{C}>\mathrm{T}$ polimorfizma između pojedinaca sa NT i prekomernom težinom/gojaznih; ni u slučaju kada su bili podeljeni na one sa prekomernom težinom naspram NT, niti kada smo uporedili gojazne naspram onih normalne težine. Međutim, analiza stratifikovana po polu je pokazala značajan zaštitni efekat TT genotipa protiv gojaznosti kod muškaraca i povećanog obima struka kod žena. Takođe,

List of abbreviations: BMI, Body mass index; NW, normal weight; Cl, confidence interval; OR, Odds ratio; PCR-RFLP, Polymerase Chain Reaction-Restriction Fragment Length Polymorphisms; bp, Base pairs; $\mathrm{p}, \mathrm{P}$ value-Statistical significance; $\mathrm{s}$, Second; min, Minute; HWE, Hardy-Weinberg Equilibrium. 
in females. Also, overweight/obese individuals with TT genotype had less risk of high cholesterol or triglycerides than overweight/obese subjects with the other genotypes. Conclusions: These results suggest that the MTHFR 677T polymorphism might not be a risk factor for being overweight/obesity. Rather, on the basis of our results, this variant could be a protector effect. However, further largescale population-based studies are still necessary to clarify the role of the MTHFR $677 \mathrm{C}>\mathrm{T}$ polymorphism in overweight, obesity, and lipid profile level.

Keywords: MTHFR, $677 \mathrm{C}>\mathrm{T}$, obesity, overweight, biochemical variables

\section{Introduction}

Overweight and obesity have become a serious public health problem worldwide since they increase the risk of chronic diseases and early death (1). Overweight and obesity are disorders of energy balance with excessive fat storage. According to the World Health Organization (WHO), obesity has increased more than twofold in the last three decades worldwide; in 2014, it was reported that more than 1,900 million people over the age of 18 years were overweight, and of those, over 600 million were obese (2). In Mexico, in the most recent report by the National Survey of Health and Nutrition, the prevalence of overweight and obesity in people over the age of 20 , adolescents, and children was $72.5 \%$, $36.3 \%$ and $33.2 \%$, respectively (3). Obesity is a multifactorial disease that involves environmental and genetic factors (4). Candidate genes associated with obesity include the methylenetetrahydrofolate reductase gene (MTHFR), located in 1p36.3, of which the rs1801133 polymorphism (677C>T; $\mathrm{A} 222 \mathrm{~V}$ ) is the most common and majorly studied (5). MTHFR is a pivotal enzyme in folate metabolism, since catalyze 5,10-methylenetetrahydrofolate to 5methyltetrahydrofolate. Moreover, it regulates the proportional usage of one-carbon units between methylation reactions and nucleic acid synthesis. The 677 TT genotype is associated with a reduction in the availability of folate, high homocysteine levels, reduced enzyme activity, and thermolabile enzyme (6). Moreover, the 677T allele has been linked with overweight/obesity risk, dyslipidemias, and diabetes in several populations. However, so far, the studies have been controversial (4, 5, 7-12, 14-30). Here, we analyzed whether there is an association of the MTHFR $677 C>$ T polymorphism with overweight and obesity, as well as its relationship with lipid profile, glucose level, and anthropometric measurements in a young Mexican population.

\section{Materials and Methods}

Three hundred and sixteen students, 232 females and 84 males, from the Multidisciplinary osobe sa preteranom težinom/gojazne osobe sa TT genotipom imale su manje rizika od visokog holesterola ili triglicerida nego osobe prekomerne težine/gojazne osobe sa drugim genotipovima.

Zaključak: Ovi rezultati ukazuju na to da polimorfizam MTHFR $677 C>T$ možda nije faktor rizika za preveliku težinu/gojaznost. Potpuno suprotno, naši rezultati pokazuju da ova varijanta može imati zaštitni efekat. Ipak, potrebne su dodatne studije širokog opsega da bi se pojasnila uloga MHTFR 677 C > T polimorfizma u prekomernoj težini, gojaznosti i nivou lipidnog profila.

Ključne reči: MTHFR $677 C>T$, gojaznost, prekomerna težina, biohemijske promenljive

Academic Unit Reynosa Aztlán of the Autonomous University of Tamaulipas, in Reynosa, Tamaulipas, Mexico were enrolled in this study. Individuals were od the average age of 19, without apparent comorbidities (hypertension, diabetes, or dyslipidemia). All of them had their weight (kilogram; kg), and height (meter; $\mathrm{m}$ ) measured. They were weighted in a precision balance with very light clothes and no shoes. Body mass index (BMI) was calculated as weight $(\mathrm{kg})$ divided by height squared $\left(\mathrm{m}^{2}\right)$. The BMI was classified as normal weight (NW) (18.5-24.9 $\left.\mathrm{kg} / \mathrm{m}^{2}\right)$, overweight (25.0-29.9 $\left.\mathrm{kg} / \mathrm{m}^{2}\right)$, and obesity $\left(\geq 30.0 \mathrm{~kg} / \mathrm{m}^{2}\right)$ (2). Moreover, waist circumference was measured in all participants; in females, $88 \mathrm{~cm}$ was considered normal, and $\geq 88$ was considered elevated, in males, $<102 \mathrm{~cm}$ (normal) and $\geq 102$ (elevated). Glucose, cholesterol, and triglycerides were determined in an analyzer AutoKem II (KontroLab, Roma, Italy). Reference values ( $\mathrm{mmol} / \mathrm{L}$ were as follows: for glucose, normal $(\leq 5.55)$ and high (>5.55); for cholesterol, normal $(\leq 5.2)$ and high (>5.2); for triglycerides, normal ( $\leq 1.71$ ) and high (>1.71). This study was approved by the ethics committee of each participating institute. Every individual was asked for informed consent to take part in this research.

\section{Genotyping by PCR-RFLP}

Genomic DNA was isolated from peripheral blood by CTAB-DTAB (denaturing cationic detergents, to precipitate DNA) and Miller (salting out the cellular proteins by dehydration and precipitation with a saturated $\mathrm{NaCl}$ solutions) methods (13). Genotyping was performed using PCR-RFLP with the following primers: 5'-TGAAGGAGAAGGTGTCTGCG GGA-3' 5'-AGGACGGTGCGGTGAGAGTG-3' a total of $100 \mathrm{ng}$ genomic DNA was amplified in a $20 \mu \mathrm{L}$ $\mathrm{PCR}$ reaction, $\mathrm{PCR}$ buffer containing $3 \mathrm{mmol} / \mathrm{L}$ $\mathrm{MgCl}_{2}, 0.25 \mathrm{mmol} / \mathrm{L}$ dNTP's (Bioline), $5 \mathrm{pmol}$ of each primer, $1 \cup$ Taq polymerase. The PCR cycles were as follows: primary denaturation was carried at $94{ }^{\circ} \mathrm{C}$ for $4 \mathrm{~min}$ followed by 35 cycles of $94^{\circ} \mathrm{C}$ for 30 $\mathrm{s}, 61^{\circ} \mathrm{C}$ for $30 \mathrm{~s}, 72^{\circ} \mathrm{C}$ for $30 \mathrm{~s}$. The final extension 
was carried out at $72{ }^{\circ} \mathrm{C}$ for $7 \mathrm{~min}$ (14). Thus, a fragment of 198 base pairs (bp) was obtained; $10 \mu \mathrm{L}$ of the PCR product was digested by 4 hours at $37^{\circ} \mathrm{C}$ with the enzyme Hinf I (BioLabs, New England, USA); the digestion products were separated in polyacrylamide gels. Homozygous individuals for the wild allele (CC) result in a fragment of 198 base pair (bp); heterozygous (CT) two fragments (198 bp and 175 bp) and homozygous (TT) a fragment of $175 \mathrm{bp}$.

\section{Statistical analysis}

Allelic and genotypic frequencies were established by counting and the distribution of the genotypes between both groups was compared by Chi-square test. Hardy-Weinberg equilibrium (HWE) was analyzed by Fisher exact test. Association was estimated by odds ratio (OR) and 95\% confidence interval $(\mathrm{CI})$ in SPSS v10.0 software (the $\mathrm{C}$ allele was taken as reference), $\mathrm{p} \leq 0.05$ was considered significant. Likewise, in overweight and obese individuals, risk factors such as glucose, triglycerides, and cholesterol were assessed. Moreover, analysis of means of anthropometric measurements and metabolic traits was evaluated according to the genotype by Kruskal-Wallis test (available at http://vassarstats.net/kw3.html)

\section{Results}

One hundred and seventy-two individuals were NW, 74 overweight, and 70 obese. Allelic and genotypic frequencies of the MTHFR $677 \mathrm{C}>\mathrm{T}$ polymorphism are shown in the Table I. Allele frequency in NW was consistent with $\operatorname{HWE}(p=0.65)$. There was no difference in the distribution of this polymorphism between NW and overweight/obese individuals $[O R=0.94(0.69-1.28) ; p=0.69]$, nor when they were divided by NW vs overweight, or NW vs obese $[\mathrm{OR}=0.87(0.59-1.3) ; \mathrm{p}=0.47]$ and [OR $=0.99$ (0.67-1.47); $p=0.96]$, respectively (Table I). However, when the sample was stratified by gender, significant differences between NW males vs obese males were observed (Table II), suggesting a protector effect for obesity of the $\mathrm{T}$ homozygotes. Regarding the analysis of waist circumference, stratified by gender, this showed that the females carrying the $\mathrm{T}$ allele had a minor risk of having

Table I Analysis of allelic and genotypic frequencies of the MTHFR $677 \mathrm{C}>\mathrm{T}$ polymorphism between individuals with normal weight, overweight/obese, overweight, and obese.

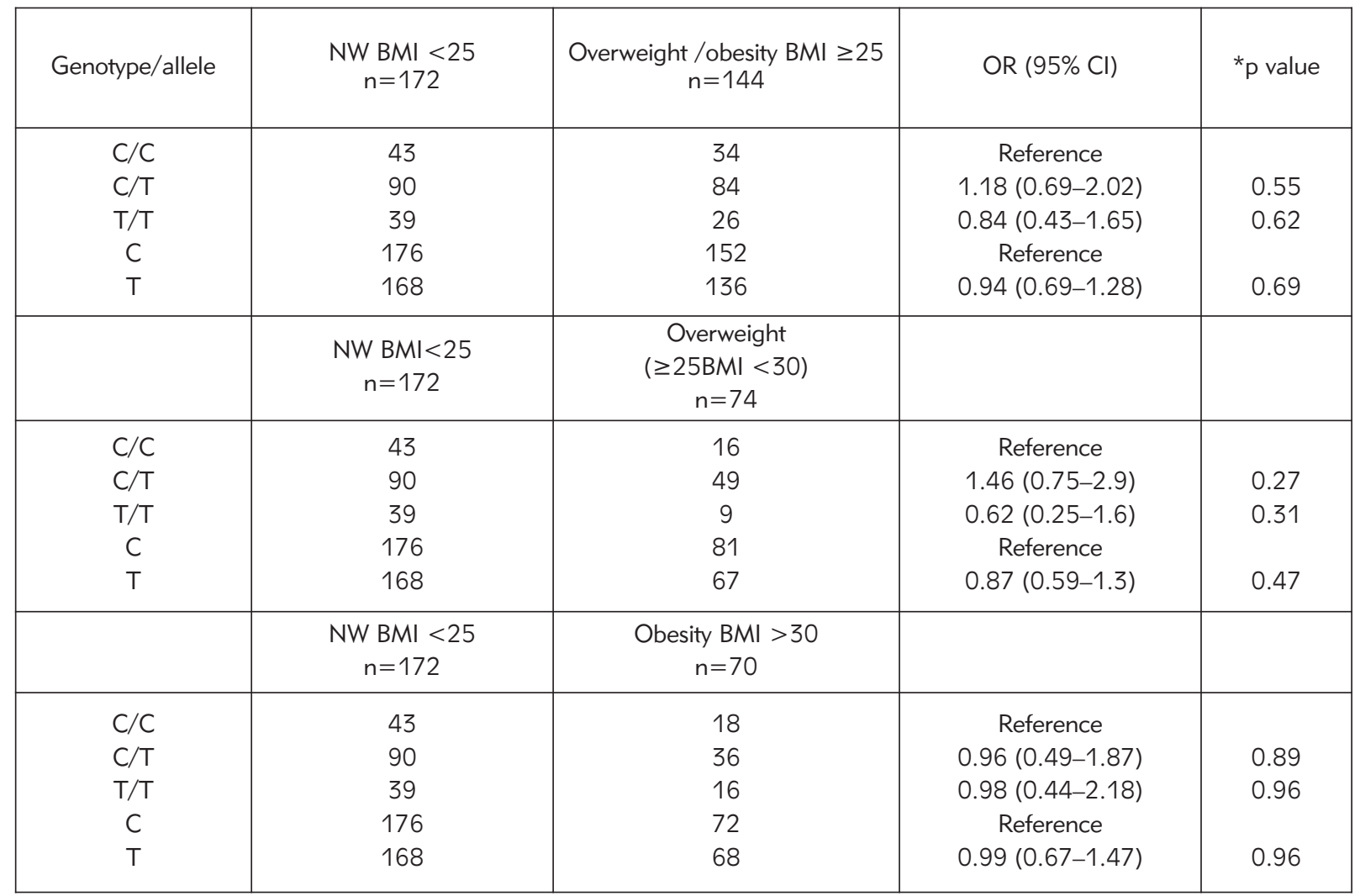

*Chi square test. 
Table II Analysis of allelic and genotypic frequencies of the MTHFR $677 \mathrm{C}>$ T polymorphism between males with BMI $<25$ vs $\mathrm{BMI} \geq 25$ and females with waist circumference $<88 \mathrm{~cm}$ vs $\geq 88 \mathrm{~cm}$.

\begin{tabular}{|c|c|c|c|c|}
\hline Genotype/allele & $\begin{array}{c}\text { Male } \mathrm{BMI}<25 \\
\mathrm{n}=37\end{array}$ & $\begin{array}{c}\text { Male } B M I \geq 25 \\
n=47\end{array}$ & OR $(95 \% \mathrm{Cl})$ & ${ }^{*} \mathrm{p}$ value \\
\hline $\mathrm{C} / \mathrm{C}$ & 7 & 18 & Reference & \\
\hline $\mathrm{C} / \mathrm{T}$ & 21 & 23 & $0.43(0.15-1.22)$ & 0.10 \\
\hline $\mathrm{T} / \mathrm{T}$ & 9 & 6 & $0.26(0.07-1.00)$ & $<0.05$ \\
\hline C & 35 & 59 & Reference & \\
\hline $\mathrm{T}$ & 39 & 35 & $0.53(0.29-0.99)$ & $<0.05$ \\
\hline Genotype/allele & $\begin{array}{c}\text { Female }<88 \mathrm{~cm} \\
n=155\end{array}$ & $\begin{array}{c}\text { Female } \geq 88 \mathrm{~cm} \\
n=77\end{array}$ & OR $(95 \% \mathrm{Cl})$ & ${ }^{*} p$ value \\
\hline $\mathrm{C} / \mathrm{C}$ & 36 & 43 & Reference & \\
\hline $\mathrm{C} / \mathrm{T}$ & 79 & 22 & $0.23(0.12-0.45)$ & $<0.001$ \\
\hline $\mathrm{T} / \mathrm{T}$ & 40 & 12 & $0.25(0.12-0.55)$ & $<0.001$ \\
\hline C & 151 & 108 & Reference & \\
\hline $\mathrm{T}$ & 159 & 46 & $0.40(0.27-0.61)$ & $<0.001$ \\
\hline
\end{tabular}

Table III Analysis of allelic and genotypic frequencies of the MTHFR 677C>T polymorphism between overweight/obese individuals depending on the level of triglycerides, cholesterol, and glucose.

\begin{tabular}{|c|c|c|c|c|}
\hline Genotype/alleles & $\begin{array}{c}\text { Overweight /obesity } \\
\text { triglycerides } \leq 1.71 \mathrm{mmol} / \mathrm{L} \\
\mathrm{n}=109\end{array}$ & $\begin{array}{c}\text { Overweight /obesity } \\
\text { triglycerides }>1.71 \mathrm{mmol} / \mathrm{L} \\
\mathrm{n}=35\end{array}$ & OR $(95 \% \mathrm{Cl})$ & ${ }^{*} \mathrm{p}$ value \\
\hline $\mathrm{C} / \mathrm{C}$ & 25 & 12 & Reference & \\
\hline $\mathrm{C} / \mathrm{T}$ & 60 & 21 & $0.73(0.31-1.70)$ & 0.47 \\
\hline$T / T$ & 24 & 2 & $0.17(0.04-0.86)$ & 0.02 \\
\hline C & 110 & 45 & Reference & \\
\hline \multirow[t]{2}{*}{$\mathrm{T}$} & 108 & 25 & $0.57(0.32-0.99)$ & 0.04 \\
\hline & $\begin{array}{c}\text { Overweight /obesity } \\
\text { cholesterol } \leq 5.2 \mathrm{mmol} / \mathrm{L} \\
\mathrm{n}=126\end{array}$ & $\begin{array}{c}\text { Overweight /obesity } \\
\text { cholesterol }>5.2 \mathrm{mmol} / \mathrm{L} \\
\mathrm{n}=18\end{array}$ & & \\
\hline $\mathrm{C} / \mathrm{C}$ & 30 & 6 & Reference & \\
\hline $\mathrm{C} / \mathrm{T}$ & 70 & 12 & $0.86(0.29-2.50)$ & 0.78 \\
\hline$T / T$ & 26 & 0 & $0.09(0.01-1.65)$ & 0.02 \\
\hline C & 130 & 24 & Reference & \\
\hline \multirow[t]{2}{*}{$\mathrm{T}$} & 122 & 12 & $0.53(0.26-1.11)$ & 0.09 \\
\hline & $\begin{array}{c}\text { Overweight /obesity glucose } \\
\leq 5.55 \mathrm{mmol} / \mathrm{L} \\
\mathrm{n}=111\end{array}$ & $\begin{array}{c}\text { Overweight /obesity glucose } \\
>5.55 \mathrm{mmol} / \mathrm{L} \\
\mathrm{n}=33\end{array}$ & & \\
\hline $\mathrm{C} / \mathrm{C}$ & 28 & 9 & Reference & \\
\hline $\mathrm{C} / \mathrm{T}$ & 65 & 18 & $0.86(0.35-2.15)$ & 0.75 \\
\hline $\mathrm{T} / \mathrm{T}$ & 18 & 6 & $1.04(0.32-3.41)$ & 0.95 \\
\hline C & 121 & 36 & Reference & \\
\hline $\mathrm{T}$ & 101 & 30 & $0.99(0.58-1.73)$ & 0.99 \\
\hline
\end{tabular}

*Chi square test. 
Table IV Analysis of anthropometric measurements, lipid, and glycemic traits in 316 Mexican youths according the MTHFR 677C > T genotype.

\begin{tabular}{|c|c|c|c|c|}
\hline Trait & $\mathrm{CC}$ & $\mathrm{CT}$ & TT & $p$ value* \\
\hline$n$ & 80 & 172 & 64 & \\
\hline Age (years) & $19.5 \pm 1.9$ & $19.7 \pm 1.8$ & $20.0 \pm 3.6$ & 0.34 \\
\hline BMI $\left(\mathrm{kg} / \mathrm{m}^{2}\right)$ & $25.9 \pm 6.4$ & $25.8 \pm 5.9$ & $25.8 \pm 7.8$ & 0.63 \\
\hline Hip circumference $(\mathrm{cm})$ & $99.2 \pm 13.0$ & $99.7 \pm 13.7$ & $98.5 \pm 12.8$ & 0.68 \\
\hline Waist circumference $(\mathrm{cm})$ & $89.9 \pm 22.9$ & $90.1 \pm 21.0$ & $98.5 \pm 17.4$ & 0.03 \\
\hline **Waist hip ratio & $0.84 \pm 0.7$ & $0.84 \pm 0.7$ & $0.83 \pm 0.7$ & 0.79 \\
\hline Systolic pressure (mm Hg) & $108.6 \pm 18.5$ & $106.5 \pm 13.5$ & $104.3 \pm 14.9$ & 0.63 \\
\hline Diastolic pressure $(\mathrm{mm} \mathrm{Hg})$ & $75.6 \pm 10.0$ & $74.8 \pm 10.1$ & $72.7 \pm 9.6$ & 0.33 \\
\hline Total cholesterol (mmol/L) & $4.18 \pm 1$ & $4.04 \pm 1.93$ & $3.88 \pm 0.75$ & 0.22 \\
\hline Triglycerides (mmol/L) & $1.19 \pm 0.69$ & $1.17 \pm 0.4$ & $1.04 \pm 0.49$ & 0.18 \\
\hline Glucose (mmol/L) & $4.8 \pm 0.79$ & $4.93 \pm 1.18$ & $4.85 \pm 0.82$ & 0.88 \\
\hline
\end{tabular}

Data are expressed as mean \pm standard deviation. BMI: body mass index. *Kruskal-Wallis test (available at http://vassarstats.net/kw3.html). ${ }^{* *}$ Genotypes of waist hip ratio were 73, 148, and 61 for CC, CT, and TT, respectively.

elevated waist circumference, both CT genotype and TT homozygote; but this was not observed in males (Table II). Testing between overweight/obese individuals based on glucose, cholesterol, and triglycerides levels, showed that the TT genotype was more common in subjects with triglycerides $\leq 1.71 \mathrm{mmol} / \mathrm{L}$ and cholesterol $\leq 5.2 \mathrm{mmol} / \mathrm{L}$ (Table III). As for the analysis of quantitative variables according to genotype, only significant differences were detected for waist circumference, and individuals with TT genotype had a larger waist circumference than CC and TT subjects $(p=0.03 ;$ Table IV).

\section{Discussion}

Besides known causes involved in overweight/ obesity development (poor eating habits, lack of physical activity, and psychological disorders), genetics plays a very important role, since it represents up to $70 \%$ of factors associated with overweight/obesity (4). The results of this study showed no statistical differences about the prevalence of the MTHFR $677 \mathrm{C}>\mathrm{T}$ polymorphism between NW and overweight/obesity individuals, which agrees with the majority of researches $(4,8,10-12,14,17,18,20$, $22,29)$. However, opposite findings have also been described; so Lambrinoudaki et al. (9) observed that healthy postmenopausal women carrying the $677 \mathrm{CT}$ or 677TT genotype had central adiposity and waist higher hip ratio compared with women carrying the 677CC genotype. Tabassum et al. (19) reported association of $677 \mathrm{C}>\mathrm{T}$ polymorphism with overweight/obesity [1.24 (1.01-1.52) $\mathrm{p}=0.04]$ in Indian population. Similarly, Di Renzo et al. (7) studied 56 obese individuals who underwent a diet and observed that before starting the regime there were more obese who carried the $\mathrm{T}(+)$ genotype (CT or TT) and less with T (-) genotype (CC carriers). They found that after twelve weeks the subjects who carried the $\mathrm{T}(-)$ genotype (CC homozygote) decreased more weight than the T allele carriers (CT or TT) (5). Others researchers suggest that overweight/obese individuals with MTHFR 677TT genotype are at increased risk for type 2 diabetes mellitus (30).

To our knowledge, the finding that carrier females of the MTHFR 677 T allele have a minor risk of elevated waist circumference has not been reported in healthy people, but Wang et al. analyzed this parameter between patients with metabolic syndrome from China and they found a trend towards a protector effect against elevated waist circumference in the patients with the TT genotype $[O R=0.60(0.27-1.32) ; p=0.204]$ (31), which is in accordance with our observations. On the other hand, the analysis of means of anthropometric measurements showed that waist circumference was increased in individuals with TT genotype. Although this looks like a contradiction, it could be explained by an unequal distribution of the people with abdominal obesity and the size sample.

Regarding lipid profiles, the MTHFR 677T allele is associated in non-obese patients with unfavourable serum lipid profiles in several studies $(15,18,21,24$, $26,28)$. In this study, we detected low levels of triglycerides and cholesterol in overweight/obese individuals carrying the TT genotype. In contrast to 
our observation, Zhi et al. (27) found that overweight/obese females carrying the TT genotype had high triglycerides levels $(p=0.0007)$, and in overweight/obesity males, the CT carriers had significantly higher LDL-cholesterol levels than the TT carriers did $(p=0.018)$ in Chinese population. Moreover, Di Renzo et al. (23) studying obese women with metabolic syndrome who underwent a diet, found that CC carriers had lower triglycerides and minor fasting glucose $(p \leq 0.05)$.

On the other hand, it is known that the TT genotype is associated with high homocysteine levels (6). Moreover, the significant increment of cholesterol has been detected in diet-induced hyperhomocysteinemic rats (32). Accordingly, it has been suggested that elevation of homocysteine increases HMG-CoA reductase expression, which in turn activates three transcription factors: sterol regulatory element-binding protein 2 (SREBP-2), cyclic adenosine monophosphate response element-binding protein (CREB), and nuclear factor $Y$ (NF-Y), and likely increases cholesterol biosynthesis, with subsequent hypercholesterolemia (32). In this study, we did not evaluate the plasma homocysteine levels. Contradictorily, our results suggest that individuals carrying the TT genotype have a minor risk to develop high levels of triglycerides, and cholesterol.

Discordances observed among studies may be occasioned by several factors such as differences in dietary, physical activity habits, genetic background,

\section{References}

1. Chan RS, Woo J. Prevention of overweight and obesity: how effective is the current public health approach. Into J Environ Res Public Health 2010; 7: 765-83.

2. World Health Organization. Fact sheet: obesity and overweight 2016. Available from: online: http://www. who.int/mediacentre/factsheets/fs311/en/

3. Shamah Levy T, Cuevas Nasu L, Rivera Dommarco J, Hernández Ávila M. Encuesta Nacional de Salud y Nutrición de Medio Camino ENSANUT MC. 2016. Available from: onlinehttp://promocion.salud.gob.mx/ dgps/descargas1/doctos_2016/ensanut_mc_2016310oct.pdf

4. Fan SJ, Yang BY, Zhi XY, He M, Wang D, Wang YX, et al. Are MTHFR C677T and MTRR A66G Polymorphisms Associated with Overweight/Obesity Risk? From a CaseControl to a Meta-Analysis of 30,327 Subjects. Int J Mol Sci 2015; 16: 11849-63.

5. Di Renzo L, Rizzo M, lacopino L, Sarlo F, Domino E, Jacoangeli $F$, et al. Body composition phenotype: Italian Mediterranean Diet and C677T MTHFR gene polymorphism interaction. Eur Rev Med Pharmacol Sci 2013; 17: 2555-65.

6. Frosst $P$, Blom HJ, Milos R, Goyette P, Sheppard CA, Matthews RG, et al. A candidate risk factor for gender differences, sample size, statistical analysis criteria, and the participation of other genes that coding enzymes involved in the homocysteine pathway. We only investigated one polymorphism and did not have data on other environmental factors, such as physical activity, dietary habits, alcohol consumption and cigarette smoking. We consider that identification of polymorphisms associated with obesity and overweight in young individuals will allow the detection of people in risk at an early age, which could to permit to take preventive actions.

In conclusion, these results suggest that the MTHFR 677T polymorphism might not be a risk factor for being overweight/obese. Rather, on the basis of our results, this variant could be a protector effect. However, further large-scale population-based studies are still necessary to clarify the role of the MTHFR $677 \mathrm{C}>\mathrm{T}$ polymorphism in overweight, obesity, and lipid profile level.

Acknowledgements. Research supported by Universidad Autónoma de Tamaulipas through grant UAT10-SAL-0306. JRRL was supported by CONACyT fellowship.

\section{Conflict of interest statement}

The authors stated that they have no conflicts of interest regarding the publication of this article.

vascular disease: a common mutation in methylenetetrahydrofolate reductase. Nat Genet 1995; 10: 111-3.

7. Al-Batayneh MK, Al Zoubi SM, Shehab M, Al-Trad B, Bodoor K, Al Khateeb W, Aljabali AAA, Al Hamad M, Eaton G. Association between MTHFR 677C>T Polymorphism and Vitamin B12 Deficiency: A CaseControl Study. J Med Biochem 2018; 37: 141-7.

8. Milošević Georgiev A, Krajnović D, Kotur-Stevuljević J, Ignjatović S, Marinković V. Undiagnosed Hyperglycaemia and Hypertension as Indicators of the Various Risk Factors of Future Cardiovascular Disease Among Population of Serbian Students. J Med Biochem 2018; 37: 289-89.

9. Lambrinoudaki I, Kaparos G, Papadimitriou D, Sergentanis TN, Creatsa M, Alexandrou A, et al. Methylenetetrahydrofolate reductase $\mathrm{C} 677 \mathrm{~T}$ polymorphism is associated with central adiposity and increased androgenicity in healthy postmenopausal women. Eur J Endocrinol 2008; 159: 233-41.

10. Lewis S, Lawlor DA, Nordestgaard BG, Tybjærg-Hansen A, Ebrahim S, Zacho J. The methylenetetrahydrofolate reductase C677T genotype and the risk of obesity in three large population-based cohorts. Eur J Endocrinol 2008; 159: 35-40. 
11. Liu X, Zhao L, Liu YJ, Xiong DH, Recker RR, Deng HW. The MTHFR gene polymorphism is associated with lean body mass but not fat body mass. Hum Genet 2008; 123: 189-96.

12. Settin AA, Algasham A, Dowaidar M, Ismail $H$. Methylene tetrahydrofolate reductase and angiotensin converting enzyme gene polymorphisms related to overweight/obesity among Saudi subjects from Qassim Region. Dis Markers 2009; 27: 97-102.

13. Miller SA, Dykes DD, Polesky HF. A simple salting out procedure for extracting DNA from human nucleated cells. Nucleic Acids Res 1988; 16: 1215.

14. Tavakkoly-Bazzaz J, Shojapoor M, Nazem H, Amiri P, Fakhrzadeh H, Heshmat R, et al. Methylenetetrahydrofolate reductase gene polymorphism in diabetes and obesity. Mol Biol Rep 2010; 37: 105-9.

15. Zhang L, Yin RX, Liu WY, Miao L, Wu DF, Aung LH, et al. Association of methylenetetrahydrofolate reductase C677T polymorphism and serum lipid levels in the Guangxi Bai Ku Yao and Han populations. Lipids Health Dis 2010; 9: 123.

16. Frelut ML, Nicolas JP, Guilland JC, de Courcy GP. Methylenetetrahydrofolate reductase $677 \mathrm{C}$-> T polymorphism: a link between birth weight and insulin resistance in obese adolescents. Int J Pediatr Obes 2011; 6: e312-7.

17. Gara S, Ochi H, Chango A, Najjar L, Feki M, B'chir F, et al. C677T polymorphism of MTHFR and G80A polymorphism of RFC genes and their relation with homocysteine levels in obese Tunisian children. Tunis Med 2011; 89: 565-8.

18. Chauhan G, Kaur I, Tabassum R, Dwivedi OP, Ghosh S, Tandon N, et al. Common variants of homocysteine metabolism pathway genes and risk of type 2 diabetes and related traits in Indians. Exp Diabetes Res 2012; 2012: 960318.

19. Tabassum R, Jaiswal A, Chauhan G, Dwivedi OP, Ghosh $\mathrm{S}$, Marwaha RK, et al. Genetic variant of AMD1 is associated with obesity in urban Indian children. PLoS One 2012; 7: e33162.

20. Yin RX, Wu DF, Aung LH, Yan TT, Cao XL, Long XJ, et al. Several lipid-related gene polymorphisms interact with overweight/obesity to modulate blood pressure levels. Int J Mol Sci 2012; 13: 12062-81.

21. Chmurzynska A, Malinowska AM, Twardowska-Rajewska J, Gawecki J. Elderly women: Homocysteine reduction by short-term folic acid supplementation resulting in increased glucose concentrations and affecting lipid metabolism (C677T MTHFR polymorphism). Nutrition 2013; 29: 841-4.

22. Hernández-Guerrero C, Romo-Palafox I, Díaz-Gutiérrez MC, Iturbe-García M, Texcahua-Salazar A, Pérez-Lizaur $A B$. Prevalence of metilentetrahidrofolate reductase C677T polymorphism, consumption of vitamins B6, B9, B12 and determination of lipidic hydroperoxides in obese and normal weight Mexican population. Nutr Hosp 2013; 28: 2142-50.

23. Di Renzo L, Marsella LT, Sarlo F, Soldati L, Gratteri S, Abenavoli L, et al. C677T gene polymorphism of MTHFR and metabolic syndrome: response to dietary intervention. J Transl Med 2014; 12: 329.

24. Jiang S, Zhao R, Pan M, Venners SA, Zhong G, Hsu YH. Associations of MTHFR and MTRR polymorphisms with serum lipid levels in Chinese hypertensive patients. Clin Appl Thromb Hemost 2014; 20: 400-10.

25. Villela MP, Andrade VL, Eccard B, Jordão AA, Sertório JT, Tanus-Santos JE, et al. Homocysteine and nitrite levels are modulated by MTHFR $677 \mathrm{C}>\mathrm{T}$ polymorphism in obese women treated with simvastatin. Clin Exp Pharmacol Physiol 2014; 41: 744-7.

26. Wen C, Lv JF, Wang L, Wan FS, Wang XZ. Association of a methylene tetrahydrofolate reductase $\mathrm{C} 677 \mathrm{~T}$ polymorphism with several blood chemical levels in a Chinese population. Genet Test Mol Biomarkers 2015; 19: 24 9.

27. Zhi X, Yang B, Fan S, Wang Y, Wei J, Zheng Q, et al. Gender-specific interactions of MTHFR C677T and MTRR A66G polymorphisms with overweight/obesity on serum lipid levels in a Chinese Han population. Lipids Health Dis 2016; 15: 185.

28. Liu Y, Li K, Venners SA, Hsu YH, Jiang S, Weinstock J, et al. Individual and joint associations of methylenetetrahydrofolate reductase C677T genotype and plasma homocysteine with dyslipidemia in a Chinese population with hypertension. Clin Appl Thromb Hemost 2017; 23: 287-93.

29. Kupcinskiene K, Murnikovaite M, Varkalaite G, Juzenas $\mathrm{S}$, Trepenaitis D, Petereit R, et al. Thrombosis Related $\mathrm{ABO}, \mathrm{F5}, \mathrm{MTHFR}$, and FGG Gene Polymorphisms in Morbidly Obese Patients. Dis Markers 2016; 2016: 7853424

30. Zhi X, Yang B, Fan S, Li Y, He M, Wang D, et al. Additive Interaction of MTHFR C677T and MTRR A66G Polymorphisms with Being Overweight/Obesity on the Risk of Type 2 Diabetes. Int J Environ Res Public Health 2016; 13: E1243.

31. Wang J, Xu L, Xia H, Li Y, Tang S. Association of MTHFR C677T gene polymorphism with metabolic syndrome in a Chinese population: a case-control study. J Int Med Res 2018; 46: 2658-69.

32. Woo CW, Siow YL, Pierce GN, Choy PC, Minuk GY, Mymin D, et al. Hyperhomocysteinemia induces hepatic cholesterol biosynthesis and lipid accumulation via activation of transcription factors. Am J Physiol Endocrinol Metab 2005; 288: E1002-10. 